\title{
John Locke's Educational Ideology with Educational Innovation in Vietnam Today
}

Huynh Thi Phuong Thuy

Van Lang University, 45 Nguyen Khac Nhu Street, Co Giang ward, District 1, Ho Chi Minh City, Vietnam

DOI: $10.36348 /$ jaep.2020.v04i09.001

| Received: 28.08.2020 | Accepted: 05.09.2020 | Published: 09.09.2020

*Corresponding author: Huynh Thi Phuong Thuy

\section{Abstract}

John Locke (1632-1704) is one of the most influential names in Western European society during the bourgeois revolutions. In his system of philosophy, education ideology plays a rather important role. Locke published a book of "Few Reflections on Education" in 1693, in which he formulated his philosophy of education. His views on education were radical for that era, and even though he wrote them nearly 400 years ago, they continue to influence the way we think about education and raising children today. Jonh Locke is a truly influential thinker and he is part of the group of British philosophers considered empirical, who believe that our knowledge and understanding of the world comes to us through "sensory experience". In the framework of the article, the author clarifies some educational ideas of J. Locke, thereby analyzing its significance for the current Vietnamese educational innovation.

Keywords: John Locke, educational ideas, English philosophy, educational innovation, Vietnam.

Copyright @ 2020: This is an open-access article distributed under the terms of the Creative Commons Attribution license which permits unrestricted use, distribution, and reproduction in any medium for non-commercial use (NonCommercial, or CC-BY-NC) provided the original author and sources are credited.

\section{INTRODUCTION}

John Locke (1632-1704) is considered to be one of the greatest representatives of the Enlightenment movement that formed in Western Europe in the late seventeenth century, a special ideological and cultural movement whose impact surpassed out of the framework of the times. The views of J. Locke spread over many different aspects, from the socio-political field with the idea of natural rights and social contracts, from which the explanation of a rational state; religious force with a spirit of religious tolerance and the freedom to choose the individual path of salvation; the economic sector with theories on values and prices, etc. including the education sector with very profound analysis.

Among the works of J. Locke, a book of Some thoughts on education are the only work he wrote about education, but since its inception, this work has received a warm reception not only in England but also in many different nations. Also translated into many other languages since the eighteenth century up to now. J. Locke's educational view has had a great influence on thinkers of his time and later, among those influenced by J. Locke is Jean Jacques Rousseau, etc. Therefore, the study of epistemology to better understand John Locke's educational ideology, which related to the current Vietnamese education reform is a necessary issue.

\section{RESEARCH CONTENT \\ Some basic content in the educational thought of John Locke}

In his philosophical system, although J. Locke does not refer to a philosophy of education that includes the system of categories nor to mention specific educational policies, through the works of him, especially some thoughts about education, his educational thoughts is still clearly expressed.

First, J. Locke emphasizes the role of education in human development in a perfect way of humanity and reason.

Education in J. Locke's reasoning plays an important role in the formation and development of people, from inanimate children, who are skeptical of the world to knowledgeable, talented people with knowledge profound about life. This is in stark contrast to one of the more popular philosophical views of $\mathrm{J}$. Locke's time, which is the innate conceptualism, which is rooted in Platonism and reformed by Descartes and the Cartesian school. This theory asserts that it seems that knowledge, as well as other human abilities, inevitably appear from the moment of birth. J. Locke 
ascribed to this argument the concept of man as a passive, free-flowing entity, through which he opposes his fundamental principles and ideals. According to J. Locke, there is no innate idea of this world, but from the very beginning, the hearts of children are like white paper (tabula rasa) and they must learn from things the simplest. This is evidenced by the fact that they cannot even comprehend the most basic words, nor recognize basic dangers such as fire or precipitation, etc. J. Locke believes, knowledge is building, tabula rasa will make room for a knowledge system of the world through education. J. Locke's critique of innate ideas, concepts, and principles through rich and convincing material is not just a critique of idealism and the defense of materialism in physics. epistemology, but also to emphasize the power and role of education in writing on white paper new ideas of life, thereby forming gentleman with virtue, wisdom, courtesy, and education. J. Locke firmly believes in the power of education, claiming, "Ninety percent of the people we meet, these people good or bad, useful or ineffective, come from education both" [1]. Therefore, "good education of children becomes the duty and right of parents, and the peace of the nation depends heavily on education, so each of us needs to take it seriously from the bottom in my heart" [2].

From the theory of tabula rasa to justifying the role of education is a necessity, but J. Locke pushes it too far by explaining that a child's soul is like a blank whiteboard, and spear education will write on that whiteboard new content from life, or the child as "a wax that the educator can mold to his own will" [1]. So is it that the task of education is to equip the child with knowledge by "cramming" mechanically? He also said that "the craftsmanship and artistry of the teacher are to remove all ideas from the child's mind before teaching him something, his mind must be cleared up so that it can take over. new knowledge; Without this condition, knowledge will not be imprinted in the child's mind "[1], and in J. Locke's principle, freedom and tolerance are not good for children, since they are not judgmental enough, so they need guidance and discipline, waiting for them to think. I think we will treat them less strictly. Influenced by J. Locke's educational philosophy, but in Jean Jacques Rousseau, a junior philosopher of $\mathbf{J}$. Locke, freedom was expressed in a more radical way from the beginning. According to Rousseau, never order the child to do anything, direct the child to understand the nature of things through his own experience. He writes, "should not be involved in educating a child when we do not know how to guide him with the rules "can" and" cannot" [3]. According to Rousseau, the educator must not impose their will on the child but must create the necessary dynamics for the child's learning and follow it closely during the life's challenges.

The cramming, imposing in the educational ideology of J. Locke was also harshly criticized by John
Dewy, an American philosopher of the nineteenth century, "for whatever reason, in spite of the fact that cram teaching, learning by passive absorption has been condemned everywhere, yet they remain firmly entrenched in practice" [4]. According to Dewey, man is a rational being, it is the educator's job and responsibility to construct man into an independent and responsible being. The teacher's role is to organize the appropriate context to teach students the present experience through the student's interaction with past experiences with the current problems and circumstances. Authentic education is to enable learners to learn based on experience, learn based on practice, learn by combining mind and body, learn by themselves building a store of knowledge and creativity learning by collaborating with others, etc.

Yet, given that Britain at that time had just experienced a fierce civil war and is slowly recovering, it was in need of gentlemen - gentlemen with the ability of their own reason to bring about prosperity development for the society. Cramming is done through the spiritual formation of the child with the influence of gentlemen as an educator with a deep knowledge of the world, customs, and practices, The strange thing, the tricks, the shortcomings of our time, especially in our country, to the student seems to be an effective and necessary measure to meet the practical requirements in the social context at that time.

Education will shape each individual from an early age, like shaping the flow for a good purpose. When individuals have matured rationally through education, they have the capacity to perceive the inevitable to be able to control and adjust their behavior within certain limits. The rational guidance, the control of the reason will guide them to the freedom to act. They decide on their own behavior and control themselves. According to J. Locke, man is truly free only if and only if he is able to perceive the capacity of behavior on the basis of clear reason. They distinguish right from wrong and act voluntarily according to certain standards under the guidance of reason and morality so that their personal freedom does not infringe upon the freedom of others. Their personal interests are guaranteed and balanced with the interests of the community and society. Education is not only a tool for people to move towards freedom through reason but also guides each individual how to survive in a society with many tricks and pitfalls of life, helping them prevention of suffering, disease, poverty, and crime, teaches them how to anticipate the plans of those with whom they work and to be vigilant in relationships. Education in J. Locke's concept is therefore practical oriented education, serving practice. The gentleman model that J. Locke built was not a man with academic and scholastic knowledge but a man with his rational ability to establish a social order stabilized after the complicated and rife conflict of the British bourgeois revolution. 
In the concept of $\mathrm{J}$. Locke, education towards the perfection of human reason must manifest in four factors: virtue, wisdom, politeness, and education. Virtue is the primary quality that every human being should have, helping the individual to be respected and loved by others, and to self-satisfaction with themselves. Virtue is also self-restraint of one's own desires, the ability to deny desires that reason does not allow. Next is wisdom with openness, fairness, and discernment. "This quality helps people to do business skillfully and foresight. This is the result of a mixture of good nature, along with the manipulation of the mind with experience" [1]. As an empiricist who emphasizes experience in human cognitive processes, J. Locke requires teaching the child actions and habits to be an honest, submissive person mind, train the child through many activities to accumulate good experiences over time. The third factor given by J. Locke is courtesy or politeness. Instead of explaining what courtesy is, he contrasts it with timidity, embarrassment, and carelessness, disrespect for others. Education is ranked last because he thinks it is the least important part of education. If the first three factors belong to the moral education to form the individual personality, the last factor belongs to intellectual education, education for the child. Thus, in his educational purposes, J. Locke focuses on building and developing the child's good ethical qualities - human education in the good sense of the word.

Second, education is the process of forming and developing a person through the accumulation of personal experience and enriching it with emotional materials.

Educating a child to become a gentleman is a difficult but not impossible task, it is a process because perception is also a process. J. Locke said that the capacity of perception, reasoning, understanding, reason is formed only through experience. Experience is the basis of knowledge, knowledge, after all, stems from experience. The thesis of experience as the source of all knowledge is the foundation of J. Locke's philosophical empiricism as well as the theoretical basis for his educational thought. Accordingly, the difference between people's perceptions is not due to differences in innate ability to perceive or transmit ideas, but from their own experiences. Asserting that all of our knowledge is formed from experience but J. Locke also distinguishes two types of experience: external experience and inner experience. External experience is composed of a combination of senses, its origin is the impact of the physical world objectively on the human sensory organs and inducing sensations. Human insights brought about by sensations are the simplest facts of perception, that is, the simplest forms of knowledge. The feeling is the starting point of all opinions and the generated sensory ideas are the first and most important ideas in a child's life. As can be seen, J. Locke developed empirical inclination in epistemology and pushed it toward sensationalism. Like Hobbles, J. Locke states "there is nothing in intellect, if not first of all in feeling" and in a child, "the arguments they accept are arguments, etc must be like what they feel and touch" [1]. From the idealistic point of view, J. Locke proposes that the child's education "directs towards the senses and gives the child a direct understanding of things" [3]. Game-based education is therefore regarded by J. Locke as easy, solid teaching. When a child is placed in the hands of an "educational toy", he can use it at will, and through direct contact with those toys, he gradually has a simple understanding of letters, children number. It is an important starting point, the only valuable preparation for learning.

J. Locke's ideological education goes further when he demands a child's experience with the entire world around them, for if they don't have their own feelings about what happened, if they didn't see it with their own eyes, they would still be as ignorant as before, no matter what the upright people said. All the experiences that educators need to do are "should be made a habit for them by practicing continuously every opportunity to do that, and create those opportunities if needed" [1]. In the process of character formation and development, the child must learn to live in society by practicing good habits and repeating these habits. According to him, doing so can evaluate the child's ability to perform and if there are things the child cannot do, when necessary, it must be taught to do and practice it. Because each child is born with different personalities, physical and intellectual abilities and $\mathrm{J}$. Locke attaches great importance to following and adjusting the educational method to suit the needs and abilities of young. "Whoever is in charge of educating children must study their nature and abilities; by regular experiments to see which nature and ability tend to favor and how to develop; observing the child's nature, how to make it better and adapting to something. Educators must see what children are missing, see if they can achieve them by practicing diligently; see if it should take the effort to practice" [1]. Obviously, the process of experimenting with many different experiences is not only for the child - the learner but also brings outside experiences to the teacher so that the teacher can come up with an appropriate educational method and optimization. This is consistent with the spirit "educators themselves also need to be educated" in Marxism-Leninism. The second benefit of practice is that by forcing a child to repeat an action over and over until it becomes a habit, the child does not need to use his mind to remember and think anymore, it will do it easily. It's as easy and natural as breathing. But it must be noted that, first of all, create those habits with kind words, gentle advice, the teacher must also regularly observe and guide the child's actions until the child reaches habit. Thus, in J. Locke, learning with practice is a very important principle and achieves a positive educational effect. 
However, experience, which is acquired through the senses, is not the only source of knowledge. The second source of knowledge is the activity of reason itself when it reflects, reflection, selfobservation, and its actions and perceives them. Reflective activity depends a lot on the cognitive subject with essential conditions both physically and mentally. In his book some thoughts on education, right in the first part "the General Principle", J. Locke affirmed, "Whoever has less wise minds never goes on the right path; and whoever has a skinny, frail body will never be able to walk on that path" [1]. Even he admits that there is still ten percent of the created people who are gifted with a body and a mind so strong that they don't need the help of anyone else and that they are capable of performing miracles. From that, it can be understood that personal characteristics, health, the mind also play an important role in the learning process. Therefore, when determining the educational method, J. Locke attaches great importance to devise a method that is suitable for the child's abilities, genius, and body. Therefore, educators must carefully study their natures and abilities with regular experiments. According to J. Locke, God created each person with his own personalities, all an educator can do is make the best use of what nature has given, or by preventing vices and mistakes that come with each temperament, or develop inherent goodness. "Everyone's genius should be developed as much as possible; but if we try to give each person a genius that it does not have, then it is only a waste, and only creates a hard, rough and artificial appearance" [1]. A wise teacher is to observe the child's temperament and create stimulation in the child's mind so that he or she will enjoy learning, saving him loads of time, effort, and effort higher efficiency. Obviously, individual gifts and qualities are undeniable factors, but if we absolutize it, assuming that education is only a stimulus for available geniuses will fall into philosophical idealism.

Inside experience, reflection, the reflection of individuals, despite having relative independence, basically depends on outside experience. J. Locke always asserted that the activity of wisdom, which becomes the object of reflection, takes place only on the basis of emotional materials, formed in the man before the ideas of reflection that the soul cannot think before sensations give it the ideas needed for thinking [2]. Therefore, J. Locke attaches great importance to activities aimed at enhancing the capacity of each individual both physically and mentally during childhood. It is medical knowledge that has contributed to J. Locke's interest in the health of the child's body, mind, and mind. According to him, first of all, it is necessary to exercise physical strength, form a healthy person with high stamina to create good working habits in the harshest natural conditions. Physical education is associated with spiritual education, human awareness, striving to become a man of work, living responsibly with family and society. Next is to equip understanding capital for children as a prerequisite for the process of entering a difficult life. On the other hand, moral education, which is the education of the good, the desire for happiness, the righteous passion, behaving according to the guidance of reason, and following the example of the sage, should be associated with the education of love teaching young people the necessary jobs, career orientation for them. In short, educators must pay attention to both the physical and mental factors of the human being, on that basis, form a positive education method - comprehensive education.

It can be seen that, in J. Locke, a gentleman - a gentleman is both the target and the driving force of education. As the driving force of education, with a clear spirit in a robust body, the gentleman will improve his comprehension ability on the path of seeking knowledge, gaining more and more life experiences from the world around them and adapting to changes in living conditions. J. Locke said, "make the habit child get the right view of things, and not self-satisfied until it is reached; elevate his mind to far-reaching and worthy thoughts; and train him to stay away from lies and deceit, for there are lies in deception; that is the best way to prepare the child for wisdom" [1]. At the same time, to form the perfect, chivalrous man - a gentleman who is physically and mentally healthy, capable of conducting his work intelligently and carefully, a gentleman, subtle communication is also a direct goal of education.

In general, J. Locke's educational philosophy was consistent with his epistemology as well as his lifeview. Besides the limitations, his educational views are still of great value beyond time, and it is a prompt for future thinkers in searching for an optimal educational model with the spirit of democracy and humanity.

\section{The meaning of John Locke educational ideology with the modern innovation of education in Vietnam}

J. Locke and his educational ideology include very practical content and its positive values that transcend all spatial and temporal frameworks. He believes that proper education, consistent with human cognitive activities, can create human perfection in all respects, the gentlemen. Society will be stable and prosperous if its members are educated to be virtue, wisdom, courtesy, and education. And vice versa, a society with an effective education will be the conditions for the growth of each member.

The values in the educational ideology of $\mathrm{J}$. Locke have been received, inherited, and developed in many different aspects by later generations. In Emile or educational problem, J. Rousseau argues that the purpose of education is to create free and happy people. The role of the educator is to train the child to become a fully human, true person with a single skill - life skill. J. Rousseau shows three types of education and three types of teachers: nature, man, and things. They all 
work together and participate in the education of people. Nature thrives within our internal organs and talents; people help us make use of that development; things affect us and give us experience. In the first stage, the child needs the care to develop a physical condition, because a new body is well adapted to its surroundings. In the period from two to twelve years old, parents need to create conditions for the child to experience, explore the world to stimulate in its creativity and self-control.

J. Locke's empirical view in education was also agreed upon and supported by John Dewey. Affirming the ability to learn through practice and experience, J. Dewey has introduced an experimental educational method, in which learners only get real knowledge by their actual activities and knowledge, Skills gained from there are truly profound levels. Like J. Locke, J. Dewey argued that the curriculum must be designed in such a way that it can meet the differences in learners' abilities and unique needs, but not be stereotyped within a program the same. According to him, education must aim for both purposes: social goals and personal ends; therefore, education must create development not only for society but also for individuals.

In Vietnam, over 30 years of comprehensive national reform, the Communist Party of Vietnam [5-7] has always affirmed: Education and training are the first national policy, investment in education is an investment. For people, towards human development, this is the basic investment, has the most lasting and reliable effect for the development of the country, so it must be given priority in the programs, socio-economic development plan. In the current context, the world is witnessing the great achievements of the modern science-technology revolution, the knowledge economy has identified the leading position of workers in the production force, with the task of "improving people's knowledge, developing human resources, fostering talents", education plays an increasingly important role in building a new generation of Vietnamese workers, meeting the requirements of development and international integration. The renovation cause in Vietnam under the leadership of the Party has achieved many important achievements, the people's material and spiritual life has been improved more and more, the position of the country on the international arena is also increasing high. Achievements in the country's renovation process have made a significant contribution to education. However, in addition to that, Vietnam's education still has many weaknesses and shortcomings, the quality of education is still low compared to the requirements. Finding the values in the educational ideology of J. Locke with the spirit of "clear, clear" is a meaningful job for educational innovation today.
In the view of J. Locke, education must aim to create a fully developed human being, both in gymnastics, ethics, and education, in which he "puts virtue at the forefront of the virtues that a human beings, educated or not, also need" [1], while education is necessary, but it should only be left in the secondary rank, depending on other higher virtues. This is similar to the requirement "to strongly shift the educational process from mainly equipping knowledge to developing comprehensively the competencies and qualities of learners" [7], "educating Vietnamese people to develop comprehensively and promote the best potentials, the creativity of each individual; love family, love the Fatherland, love people, live well and work effectively" [7] of Communist Party of Vietnam. In particular, at J. Locke, education towards training students' abilities and qualities to adapt to all life changes is more important than dogmatic and academic theories. This argument is even more significant in today's era with the rapid changes in technology, even changing hour by hour. Human knowledge is endless, increasingly endless, always changing and developing, so education must focus on equipping learners with thinking methods, creative capacities, helping them adapt to the dizzying shift of the tool of labor. Looking back at human resources in Vietnam, one of the weaknesses of workers is the lack of skills necessary for life. Therefore, reforming education to meet the requirements of integration and development is to create a generation of Vietnamese workers with the knowledge, ethics, bravery, honesty, critical thinking, creativity, life skills, professional skills and skills to solve all problems, etc. to work effectively in a globalized environment, both cooperating and competing. This requires radical changes in education and training, from content and teaching methods to building a healthy and favorable educational environment, helping learners be proactive and active, build knowledge, develop skills and apply learned things to life.

From empirical epistemology, J. Locke proposed principles of learning with practice in education. This is a very important content in renewing Vietnamese education in the direction "associating with the needs of socio-economic development, national construction and defense, with scientific and technological progress, demand for human resource and labor market development" [7]. The ultimate purpose of education is to enhance human capacity in natural transformation and social transformation to serve human needs. The education associated with the experiences, concretizing the theories of sclerosis by programs and projects for learners is really a positive educational method. Learners will find that the lesson is not boring, poor, but extremely lively, and meaningful. Only when practiced, experienced, learners not only grasp and understand the theory but also can apply the learned knowledge in a similar or new situation, thereby developing the skills of division analyze, evaluate the 
problem, and move to the creative level. Currently, in the Vietnamese education system, practice through simulation projects, internships at agencies, and enterprises are only available at university, college, and professional high schools. With the purpose of helping students improve their professional knowledge and skills, in high school levels, it is very limited, mainly the sightseeing activities with the nature of "horse riding to see flowers" and it is still possible considered an extracurricular activity. Obviously, experience regardless of school level and age is very important, not only to develop personal skills and qualities to adapt to the changes of society but also to orient Learners' understanding at the service of life.

Looking back on the historical process, centuries have passed with the changes in social life, the educational ideas of J. Locke still have practical value to today's society. Absorbing these values as an evocation and orientation will contribute to the fundamental and comprehensive renovation of Vietnam's education to meet the requirements of national development.

\section{CONCLUSION}

J. Locke's "human-centered" educational philosophy has left a lot of influence on many modern and postmodern educators. Among them are John Dewey in Democracy and Education, Maria Montessori in many studies on teaching early childhood, or the educational ideas of Humboldt, Froebel, and many others.
As the representative of British empiricism in the seventeenth century, J. Locke's educational ideology emphasizes the role of practical experience in the process of forming human capacities and qualities, from which to build So a gentleman with the spirit of democracy and humanity. Although there are still certain limitations, J. Locke's views on educating people comprehensively, especially personality improvement, focusing on adaptability to life, learning with practice. The contents have theoretical and practical significance for the current educational reform in Vietnam

\section{REFERENCES}

1. John, L. (2017). Some thoughts on education. Hanoi: Knowledge.

2. Thach, D. N., \& Chinh, D. (2018). History of Western philosophy, volume 1: From ancient philosophy to classical German philosophy. Hnoi: National Politics Truth.

3. Jean. C. (1971). Educational philosophy. Ho Chi Minh City: Youth.

4. John. D. (2008). Democracy and Education (translated by Nguyen Anh Tuan). Hanoi: Knowledge.

5. Communist Party of Vietnam. (2006). Document of the X National Congress of Representatives. Hanoi: National Politics.

6. Communist Party of Vietnam. (2011). Document of the XI National Congress of Representatives. Hanoi: National Politics.

7. Communist Party of Vietnam. (2016). Document of the XII National Congress of Representatives. Hanoi: National Politics. 